Review

\title{
The Sustainability of Agricultural Development in China: The Agriculture-Environment Nexus
}

\author{
Jialing Yu ${ }^{1}$ and Jian $\mathrm{Wu}^{2, *}$ \\ 1 School of Agricultural Economics and Rural Development, Renmin University of China, \\ Beijing 100872, China; jialing.yu@ruc.edu.cn \\ 2 School of Environment and Natural Resources, Renmin University of China, Beijing 100872, China \\ * Correspondence: jianwu@ruc.edu.cn
}

Received: 30 March 2018; Accepted: 21 May 2018; Published: 29 May 2018

\begin{abstract}
The article aims to provide an overview of China's agricultural development and its sustainability by focusing on the agriculture-environmental nexus. We first review literature regarding trends in agricultural development and driving forces. China has made impressive progress at providing food for $22 \%$ of the world's population. At the same time, severe environmental impacts have been incurred which not only affect future food security but also have impacts on other socio-economic aspects. The agricultural policies that have been put into practice have direct or indirect impacts on such environmental outcomes. We review the impacts of agricultural policies as well as conservation policies, their effectiveness, some unintended consequences and conflicts. The article concludes that technology and institutional innovation in China should emphasize more integrated sustainable development considering the agriculture-environment nexus, instead of setting incoherent and sometimes incompatible policy goals for each separate side.
\end{abstract}

Keywords: agricultural development; environmental impacts; China; sustainability; food security; agriculture-environment nexus

\section{Introduction}

Agriculture has been the foundation of China's economy for centuries and remains vital for world sustainability. There have always been "great debates" regarding China's agriculture development. The most fundamental one is whether and how China can feed her large population. China has been struggling with this challenge throughout her long history and will continue to face it as the population grows and the country becomes increasingly affluent. Furthermore, the ongoing processes of rapid economic growth and urbanization not only bring great opportunities but also new challenges to agriculture and rural society. There have been new concerns in various areas, such as food safety, agricultural non-point source pollution, etc.

China has done remarkable work in feeding $22 \%$ of the world's population with $9 \%$ of the planet's arable land, despite the biophysical and environmental limits, such as the highly uneven distribution of water resources [1]. At the same time, this has come with a price. Like the agricultural sectors in other countries, China's farms rely heavily on the ecological services of local ecosystems, including soil fertility, water resources, pollination, etc. The increasingly intensive agricultural activities lead to serious environmental pollution and over-exploitation of resources spawning serious ecological problems, such as soil and water pollution from excessive utilization of agrochemicals, soil erosion from land conversion, deforestation, etc. [2-4].

In this paper, we discuss the nexus between agricultural production and the environment from two perspectives: food security and sustainability. The paper mainly focuses on two questions: 
(1) What is the trend of China's agricultural production and what are the driving forces that contribute to meeting food demand for $22 \%$ of the world's population?

(2) On one hand, what are the environmental impacts incurred by the expansion and intensification of agricultural production? And on the other hand, how do these impacts influence the sustainability of the country's agricultural sector?

China's agricultural sector has gone through tremendous changes, including institutional transformations, structural adjustment of policies, technology advancement, etc. [5] Evidence show that from 1979 to 1984, institutional changes (de-collectivization, allocating land equally to all households in rural villages) were major sources of growth in the agricultural sector [6,7], Huang and Rozelle [8] identify technology adoption to be the major driver for production growth between 1978-1984, greater than institutional reform, and between 1985 to 1990, technology accounted for all growth after the benefit of de-collectivization was exhausted. Liu, Zhang and Herbert [1] document that by 2010, China could already grow more than $95 \%$ of its own grain, providing food security to $22 \%$ of the world's population. This achievement is notable because the country has only $9 \%$ of the world's cultivated farmland. It is estimated that a total of almost 100 billion kilograms more grain will be needed by 2030, which calls for an additional $1 \%$ annual increase in current production.

Globally, increasing demand for agricultural products often contradicts the goal of environmental protection [9]. This is particularly true for the agricultural sector in China. The successful achievement of food security has resulted in severe damages to the environment, affecting the landscape, water, nutrients, biodiversity, etc. [4,9]. The agro-related pollution sources include misuse or overuse of agrochemicals, poorly managed waste water from livestock production, contamination due to wastewater irrigation etc. Norse and Ju [4] estimate that the economic loss due to environmental damage, such as negative impacts on the sustainability of food production and human health ranges from $7 \%$ to $10 \%$ of China's agricultural gross domestic product, for example, the researchers identify the overuse of nitrogenous fertilizer as a major cause of economic loss.

In the past, an unofficial ideology of "pollute first, and then clean up" was the root of the Chinese agricultural sector's poor environmental performance [3]; however, balancing the agriculture-environment nexus is among China's current greatest challenges. Efficient and ecosystem-friendly cropping systems are increasingly studied with the goal of improving water-use efficiency and nutrient management [10,11]. Yet greater efforts are required to advance the sustainability of agricultural production, including technology advancement, such as genetically modified crops, institutional innovations regarding land tenure, and policy adjustments to encourage adoption of conservational practices. Bromley [12] emphasizes the roles of technology and rationalizing institutional and organization irregularities in order to solve the issues of increasing demand. Liu, Zhang and Herbert [1] also point out the importance of complimentary policies for land management, urbanization processes and subsidy support.

Looking toward the future, a key debate for future development of the agricultural sector is whether farming should be labor-intensive, involving small farms seeking high-value agricultural production, or capital-intensive large farms, such as those operating in the U.S. In 2013, China's central government began to encourage land transfers and the formation of large farms in order to improve efficiency. However, there are other voices about this issue, arguing that resources (such as labor and land) are fundamentally different in the two countries. One farming system, therefore, might not suit both cases. For instance, a core objective in the U.S. farming system is to save labor. Yet labor is relatively abundant in China while land is relatively scarce. Therefore, the labor-intensive small farms, conducting high-quality agriculture production, may suit China better [13]. At the same time, traditional farming systems may hold the key to food security and agro-biodiversity conservation.

Before going into the detailed discussion, we first explain the scope of the agriculture-environment nexus and the discussion around it in this article. Figure 1 is the framework of this article, in which we outline the logics of our discussion and linkages among different components. In later discussion, we present evidence from the literature to support the framework. In this article, we analyze the two 
key questions raised earlier in the framework of the agriculture-environment nexus, in which we start from the driving forces that influence the historical trends of agricultural production in China (the left). We then focus on how agriculture affects the environment through landscape, water, soil, etc., while on the other hand, how the environment has feedback effects on agriculture (the center). Then, relationships between policies for the agriculture and the environment (the right) are discussed: how the policy system affects the agriculture-environment nexus, and what is the future picture for sustainability and food security in China.

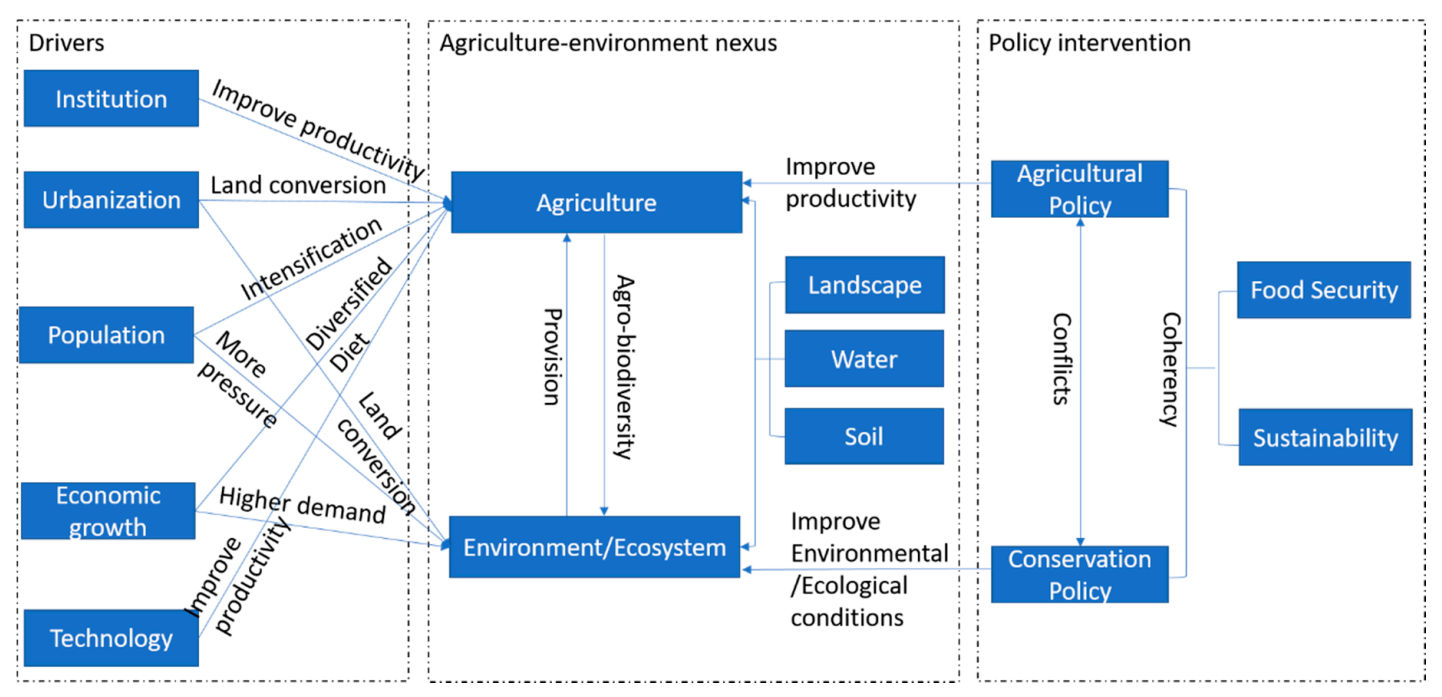

Figure 1. The agriculture-environment nexus: drivers and its policy interventions.

The remainder of this article follows the framework in Figure 1. Section 2 discusses historical trends of agricultural production in China, and the major driving forces behind recent changes. Then in Section 3, we focus on the environmental impacts/consequences of accelerated agricultural production, on water, soil, air and other media. Section 4 concentrates on public policy: what roles do agricultural and environmental policies play in the system? Section 5 looks into the future: how present and future driving forces may affect ongoing changes in China's agriculture sector that can lead to more sustainable development.

\section{The Historical Trend of Agricultural Production and Its Driving Forces}

\subsection{The Historical Records}

The remarkable achievement associated with the Chinese government's ability to feed $22 \%$ of the world's population on $9 \%$ of the planet's arable land is well-recognized. The population of China has rapidly increased over the past decades, which exerted steady pressure on China to keep expanding its agricultural production. Figure 2 shows the historical trends of population, gross value of agriculture, and grain production in China. Except for the 1958-1961 crisis shown in the figure by the decreasing trend, the agriculture sector has grown during most periods. The growth slowed down after 1997, which triggered some discussions about whether China could feed herself in the future as the population continued to grow [14,15]. The agricultural sector took off again after 2003, and China became a net exporter of agricultural commodities. Since 2008, the sector contributed to total factor productivity (TFP) growth as much as China's non-agricultural sectors [16]. By the end of 2016, grain production was 0.62 billion tons, and the cultivated land reached 13.5 million $\mathrm{km}^{2}$. Although agricultural production is growing rapidly, food security still remains a top priority in China. 


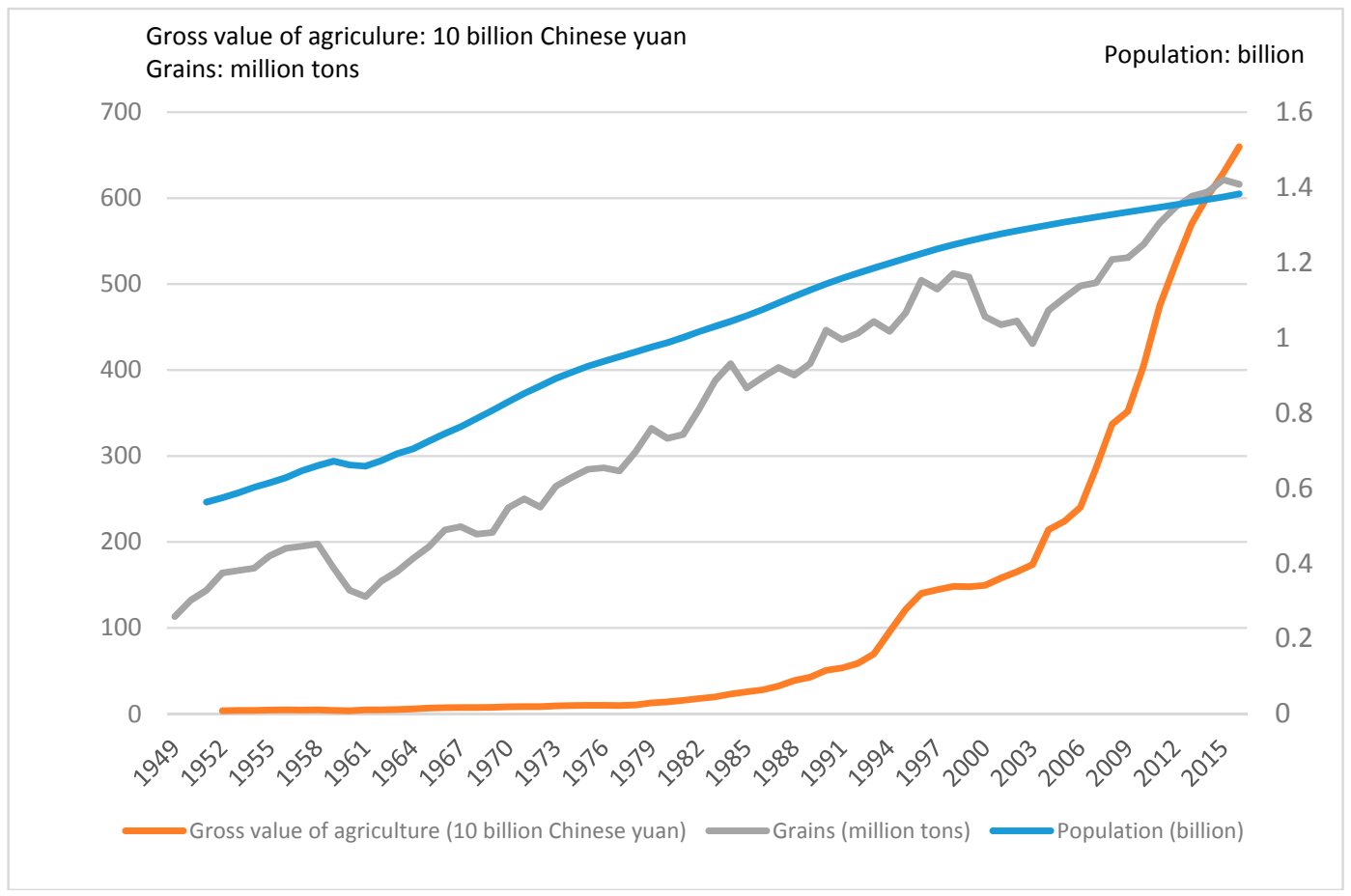

Figure 2. Historical trends of the agricultural sector in China. Data source: State Statistics Bureau http:/ / data.stats.gov.cn.

The driving forces discussed here play various roles in different stages. Theory describes how a growing agricultural sector and increasing yields responding to population change produce myriad environmental impacts (i.e., population stimulates agricultural land expansion both through consumption and production effects), agricultural intensification (through technology and modern inputs such as chemicals), and migration between rural-rural and rural-urban areas (i.e., through urbanization) [17]. These mechanisms can all be observed in China with idiosyncratic characteristics.

Many studies have been devoted to these phenomena, explaining the consequences of China's agricultural expansion $[6,8,18]$. The growth went through several stages that were driven by different factors, such as institutional changes, new technologies, the urbanization process, and some transformations in the market structures. Table 1 shows the average annual changes in population and several important components in agricultural production. Production grew relatively slowly before 1978 even though production inputs were rapidly expanded during the 1960s and 1970s [6].

The average growth rate, however, was several times greater between 1978 and 1985 than that prior to 1978 when institutional reform from the collective production system to household-responsibility system started. Before the reform, the production was organized by the production-team system consisting of 20-30 households, and farmers were rewarded by their contribution to the team. The reform started in 1978 when the production system was divided into individual households by contracting land to them, and they were rewarded by the production output of their own contract land. Lin [6] found that between 1978 and 1985, of the 42.2\% of output growth in the cropping sector, $54 \%$ can be attributed to reforms. But some $97 \%$ of productivity growth can generally be attributable to the change in farming institutions. After 1985, growth was mainly driven by the introduction of new technologies: Jin et al. [5] estimate total factor productivity (TFP) from 1980-95, and found that the TFP for rice, wheat and maize grew rapidly with new technology accounting for most of the productivity growth.

$\mathrm{Li}$ and Zhang's [19] findings indicate that the increase in agricultural inputs and TFP contributed $40.6 \%$ and 55.2\% to agricultural output growth from 1985 to 2010, respectively. Cao and Birchenall [16] use micro-level data covering the period from 1991 to 2009, and conclude that the labor input in 
agriculture decreased by $5 \%$ annually while agricultural TFP increased by $6.5 \%$. At the same time, like many developing countries, rapid urbanization brought dramatic changes to consumer food references. Aggregate dietary structure changed as income increased, requiring greater diversity in agriculture products. Livestock and vegetable productions, for instance, require more intensive input use which in turn exert greater pressure on the environment.

Table 1. Average annual growth rate of population and agricultural production.

\begin{tabular}{cccccc}
\hline Average Annual Growth Rate (\%) & $\mathbf{1 9 5 2 - 1 9 7 7}$ & $\mathbf{1 9 7 8 - 1 9 8 5}$ & $\mathbf{1 9 8 6 - 1 9 9 5}$ & $\mathbf{1 9 9 6 - 2 0 0 5}$ & $\mathbf{2 0 0 5 - 2 0 1 6}$ \\
\hline Population & 2.04 & 1.37 & 1.36 & 0.77 & 0.51 \\
Gross value of agriculture & 2.48 & 6.29 & 4.22 & 4.35 & 4.55 \\
Grain & 2.91 & 3.35 & 2.16 & 0.51 & 2.24 \\
Cotton & 5.07 & 12.21 & 2.75 & 2.81 & -0.03 \\
Oil seeds & 2.13 & 18.00 & 4.12 & 3.36 & 1.74 \\
Sugar crops & 9.34 & 14.87 & 2.84 & 3.27 & 2.79 \\
Vegetables & & & & 8.32 & 3.23 \\
Fruits & 3.88 & 6.97 & 14.13 & 17.96 & 5.27 \\
Livestock & 5.26 & 10.77 & 9.38 & 7.44 & 3.43 \\
Aquatic products & 13.10 & 9.44 & 14.82 & 7.58 & 5.03 \\
Mechanization & & 8.61 & 5.64 & 6.60 & 3.41 \\
Irrigated land & & -0.30 & 1.14 & 1.11 & 1.83 \\
Fertilizers & & 10.69 & 7.32 & 2.88 & 2.10 \\
Pesticides & & & 9.26 & 3.04 & 2.04 \\
\hline
\end{tabular}

Source: State Statistics Bureau [6].

\subsection{Driving Forces}

\subsubsection{Institutional and Policy Changes}

Institutional change is identified as the major source of growth after 1978. Chinese farming institutions were significantly affected by the country's development strategies before 1978. Historically, the independent family farm was the traditional agricultural production unit in rural China. The land reform that took place during the 1940s in China and that was completed in 1952, transferred land from landlords and redistributed it to tenant farmers. At the same time, the country's development strategy was oriented to heavy industries, aiming to build the country's capacity to produce capital goods and military materials. The 5-year plan in 1953 switched to the promotion of agricultural collectivization which was initially carried out successfully in the form of "people's communes" in 1958. By that year, the average size of these communities was 5000 households, with 10,000 labors [20].

After the 1959-1961 crisis, when 30 million people were estimated to have died of starvation and malnutrition [6], agricultural operations were divided into smaller "production teams" of about 20-30 households. At that time, land was still owned collectively, and the worker was rewarded based on his or her contribution to the collective effort. Greater emphasis was placed on modern production inputs involving more sophisticated irrigation systems, chemical fertilizers, mechanization and advanced seed and crop varieties. However, agricultural production output continued to grow slowly until further de-collectivization. Many scholars identify farming institutional reform as the major driver of production growth after 1978 [6,7]. The reform changed the production unit from collective production teams to independent family farms, with a system of contracting land, in which individuals are incentivized by their own production output instead of averaging over others' efforts in a collective system. The new system was called the household responsibility system and it was adopted in almost all rural areas in 1983. It remains in place to this day.

Accordingly, the form of local land institutions is fundamental to the increased productivity of China's agriculture sector and its rural development. Collective ownership remains the core of the land institution, but at the same time, after the 1978 reform, land-use rights have been endowed to individual households with an expectation for household responsibility [21]. The reform resulted in dramatic increases in yields and general productivity. Then, the focus of the reform has since moved to 
stabilizing land tenure, as many other socio-economic factors may conflict with sustainable utilization of agricultural land, such as urban sprawl and population growth. The first term of the land contracts from early 1980s were less secure, while in the second phase, land contract terms were extended for an additional 30 years starting from the 1990s, as enacted under the Land Management Law and Rural Land Contracting Law. The 2017 Communist Party of China National Congress announced that the contracting system will be extended for another 30 years after general expiration in 2027.

In 2015, Central Document No. 1 legally clarifies collective ownership rights, and establishes separate household contract rights along with land operational rights, known as Separation of Three Rights relating to Agricultural Land (san-quan-fen-zhi in Chinese pinyin). The three rights refer to collective ownership rights, household contract rights and operational rights, separating the operational rights from contract rights encourages small farms to transfer land to more experienced farms to benefit from economies of scale. The policy responds to a certain socio-economic background, such as the loss of labor in the agricultural sector, the abandonment of more arable land, and expanded demand for agricultural machinery. Mechanization requires a larger farm size, and leads to higher productivity. In other words, the reform aims to increase production efficiency among farmers by enabling greater economies of scale.

China's grain policy reforms are also driven by the heavy industry-oriented development strategy. Initially, the agricultural sector had to take on the financial burden by maintaining the "price scissors" between the agricultural sector and non-agricultural sector. It operated in the framework of the state-monopolized procurement and marketing system. The mandatory procurement system started in 1953, with the procurement price set at a level where the procurement and marketing agency could still make a small profit. The procurement price increased several times in 1961, 1966, 1979, 1985 and 1988 as the production output increased and the market environment changed. Both the procurement and selling prices of grain were deregulated in 1993. Even so, for a short period, the government continued to intervene for various reasons, farmers' wellbeing and market stability, to correct for the unintended effects of other policies.

\subsubsection{Technologies}

Technological advancement has been identified as the major driver for growth by various studies $[5,8,22]$. The following section discusses the nature of these technology innovations, such as irrigation, chemical inputs, genetically modified (GM) crops, and mechanized machinery.

Irrigation: Roughly $40 \%$ of irrigated land produces $75 \%$ of grain production in China [23]. Irrigation plays a significant role in food production, especially in the North China Plain (NCP). In NCP, irrigation significantly improves winter wheat production: on average irrigated wheat yields are $56 \%$ higher than rain-fed yields in the region [24]. At the same time, irrigation introduces its own challenges as it becomes increasingly vital for production. Farmers must address such problems as water shortages, pollution, low water-use efficiency and etc. The problem of water shortages and low efficiency have created new forms of farm organizations, such as water user organizations, which are established to promote cooperation in water use and to improve efficiency.

Chemical uses: Chemical uses, such as synthetic fertilizer, are thought to have contributed $19 \%$ to the productivity increase during the 1990s [22]. In 2013, the total application of fertilizers in China was 59.11 million tons which accounted for $35.5 \%$ of the world's application on only $9 \%$ of the world's arable land; and in 2016, the amount increased to 59.84 million tons. Agricultural operations in China consume far more fertilizer per unit of crop production than comparable systems in Europe or north America, and it is not surprising that China has emerged as the world's largest producer of nitrogenous fertilizer [25]. Annual herbicide use in China is also prodigious, reaching more than 1 million tons in 2015 [26]. The overuse/misuse of chemicals, as well as irrigation, contribute to the acute problem of nonpoint source pollution of surface water, groundwater and soil.

GM crops: GM crops are widely cultivated worldwide, reaching 181.5 million ha globally [27]. In China, Bt cotton was the first commercialized GM crop back in 1997; Bt rice and GM phytase maize 
was certified by the Ministry of Agriculture in 2009, and GM soybean and maize technologies were ready for commercialization in the late 2010s [28]. Qiao [29] estimate the long-term benefit of growing Bt cotton, that farmers save 4.12 billion Chinese yuan on pesticide use and 8.70 billion Chinese yuan on labor use, and the economic benefit associated with increased yields reach 33 billion Chinese yuan over 15 years of its commercialization. Huang et al. [30] report empirical evidence on the benefits to farmers' health due to reduced use of pesticides on GM rice.

Machinery use: Improving the mechanization of the agricultural sector in China has always been a key discussion topic associated with upgrading productivity. In 1980s and 1990s, machinery use appeared in rural areas as a package of customer services mostly provided by the rental market. Mechanized farming today constitutes a technological sector that is undergoing large expansion in China, encouraged by the government's purchase subsidies. In 2016, the mechanization of main crop cultivation has reached $65 \%$ of all cultivated land [31]. At the same time, land institutional reform, the aforementioned separation of three rights, that is, the separation of contract rights, allows for land transfers and facilitates the formation of large farms and optimal machinery use. Liu et al. [32] find that land transfer enhances the productivity by transferring land from less productive households to the ones with higher productivity, and machinery use reduces production cost by replacing labor. The increased machinery use is accompanied by higher agricultural income and migration rate, and land transfer and machinery use complementarily increase crop income [33].

\subsubsection{Urbanization}

The share of urban population in China increased from $21.1 \%$ to $58.5 \%$ over the period 1982-2017 [34]. The trend is expected to continue and exceed $60 \%$ by 2020 [35]. The rapid urbanization and economic development has great impacts on agriculture manifested through various channels. Urbanization leads to significant land conversion and labor migration, which have further induced problems such as arable land loss, increase of landless peasants, abandonment of arable land and emergence of hollowing/abandoned villages [36-38].

Competing land uses between urban settlements and agricultural production constitutes the core conflict, especially in some of large coastal cities. In many of these areas, arable land has gone through an aggravated conversion process to become non-agricultural, supporting industrial, transportation, residential and commercial uses. Between 2000 and 2005, the government approved land requisition of $216.4 \times 10^{4} \mathrm{ha}$. As a result of such rapid land requisition, many peasants became landless. Some of them moved to urban areas and other settlements, which accelerated the urbanization process. As a result, many villages became "hollow villages", where labor leaves and land is abandoned. Rural-urban migration is the dominant contribution to the increase of the urban population [39]. With urbanization and economic development, there were more off-farm job opportunities with higher wages further aggravating labor loss problems in the agricultural sector. One study [40] shows that as migration became easier, not only did more people tend to seek employment in urban areas, but those who stayed in rural areas reduced their labor days in agriculture. The impacts on labor supply for agricultural production increase the opportunity cost of labor-intensive farming and change production behavior and patterns [41].

\subsubsection{Market Changes}

The market structure of agricultural commodities has shifted during the processes of intensive economic growth and urbanization. Studies show that people living in urban areas have distinctly different dietary preferences than those living in rural areas [42]. Urban residents tend to consume superior grains (rice, wheat), food higher in fat, more animal products, more sugar and processed food. The changes on the demand side result in clear dietary structural changes. These include a significant shifts from consumption of coarse grains, such as sorghum, barley, rye, maize, and millet, to the consumption of rice and wheat; energy intakes increase for the poor and drop for the rich; increases in the consumption of meat, edible oil, fruit and vegetable are conspicuous [42]. As a consequence, 
between 1978 and 2002 China's per capita consumption of meat, milk and eggs increased four- and eight-fold, respectively [43]. In response to the change on the demand side, more inputs are directed to production of livestock, vegetables, fruits to keep up with the more diversified food demand, contributing to severe soil and water pollution from agricultural runoff and animal wastes.

\section{Environmental Impacts}

With the changes in agricultural production and the socio-economic environment, severe environmental impacts have occurred during the process, which not only incur direct costs but also reduce the sustainability of agricultural production.

\subsection{Land Use}

Many land-use changes can be identified within agricultural systems, such as the conversion of forests, rangelands, pastures and fishponds. The main changes in China, however, take place in the form of urban expansion $[18,44]$. As the application of new models and methods in geographic information systems (GIS) and remote sensing provide reliable data, many studies have documented land-use changes in urban areas and peripheries [45,46], especially the coastal cities [47]. Several research teams point out the association between arable land loss with urbanization and economic growth $[18,44,48]$. Evidence shows a drastic loss of arable land as a result of urbanization in China [49,50]. Jiang et al. [41] show that urban expansion is also responsible for the decline in agricultural land-use intensity. These results imply that agricultural land-use change, both in scale and intensity, is accompanied by urban expansion, and pressures on natural land resources will only increase in the future.

Studies report further ecosystem service and habitat loss along with environmental change associated with this process. For instance, the Millennium Assessment scenarios predict that at the global level, an additional $10-20 \%$ of grassland and forestland will be converted primarily to agriculture by 2050 (MEA, 2005). Similarly, China has witnessed significant wetland shrinkage in the past decades: in Sanjiang Plain, north-east China, an average annual decrease rate of 9004 ha/year, has been recorded, and approximately $83 \%$ of the conversion can be attributed to agricultural land expansion [51]. Su et al. [52] show that natural landscapes become "less dominant and aggregated, more unstable, fragmented and irregular" with the expansion of agricultural productions. Qi et al. [53] analyze land-use dynamics, fragmentation, and the variation of ecosystem service value. The team find that the rapid land-use change, especially the loss of forest lands, and socioeconomic development, are responsible for the decline in the value of ecological services in China.

\subsection{Water}

In most environments, especially in drylands, water is the key and limiting input for crop growth. Uneven distribution of water resources, however, remains a natural resource challenge for agricultural production in China. As the increase of production intensifies, over-exploitation of underground water poses an existential challenge to the sustainability of food security. There is a school of studies that focuses on water-use efficiency. Fang et al. [54] point out that enhanced irrigation and soil nutrient management are the focal issues in northern China, which must be incorporated in future strategies to improve water-use efficiency.

Besides water scarcity, pollution is another severe problem affecting agricultural production. More than $40 \%$ of China's rivers are severely polluted; $80 \%$ of lakes suffer from eutrophication [55]. This contamination is mainly caused by excessive utilization of agrochemicals along with industrial wastes. Statistical data show the contribution of the agricultural sector for chemical oxygen demand (COD) and ammonia nitrogen (N) (Figure 3). The figures demonstrate two major types of water pollution (COD and $\mathrm{N}$ ) from various sources. The agriculture source emerges as the largest contributor to COD, accounting for almost half of the total amount. It is the second largest source of $\mathrm{N}$, accounting for about one third of the total nitrogen released into surface and ground waters. Like many countries that have seen their pollution profiles change with the reduction of point source discharges, 
the agricultural component of water contamination in China is much higher than that from the industrial pollution load. Study results show that nitrate leaching was prevalent in a range of cropping systems (greenhouse vegetable, wheat-maize rotation and orchard). The groundwater in shallow wells ( $<15 \mathrm{~m}$ depth) was also heavily contaminated [56]. To relieve the pressure of water scarcity, in some regions wastewater has been reused for irrigation. The recycling has caused egregious agricultural land and food pollution, including contamination by heavy metals, which imposes health risks on consumers $[57,58]$.
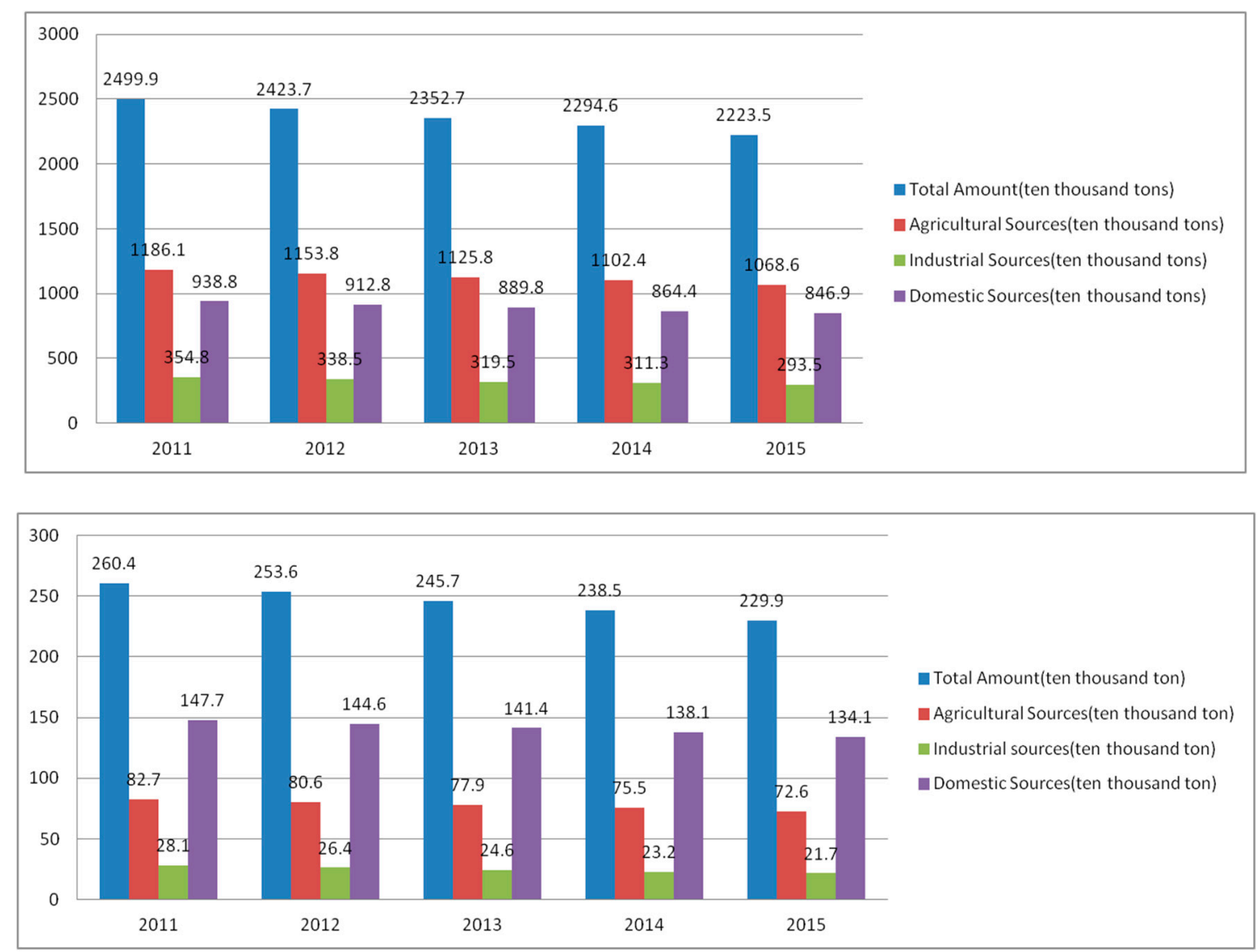

Figure 3. Discharge of COD (Top) and ammonia (Bottom) nitrogen from various sources in China. Data source: China's Environment Statistics Yearbook (2011-2015).

Climate change may exacerbate the situation of water scarcity and water pollution. Many studies have been conducted to better understand water security and agriculture production in the context of climate change. For instance, Qiu et al. [59] examine the combined impact of climate and land use on water security in northern China, and they find the water availability for agriculture in northern China is simultaneously stressed by extensive changes in land use and rapid climate change. Guo et al. [60] evaluate the responses of yields and water-use efficiencies of wheat and maize under different climate change scenarios in the North China Plain, and find that wheat yield will ascend with temperature increase while maize yield will descend in most conditions. Overall, water-use efficiencies of wheat and maize will decline because of temperature increase. Piao et al. [61] argue that current understanding is inadequate for assessing the impacts of climate change on water security, agriculture, and food security in China. 


\subsection{Soil}

As one of the most important ecosystem services, food provision relies heavily on soil, as the basic resource required for organic growth. The rising intensity of modern agricultural production and the frequent misuse of agrochemicals can heavily damage the ecosystem services that soil provides. Soil degradation and soil pollution are major concerns, which severely affect productivity and food security. Soil degradation can be caused by erosion, loss of organic matter and nutrients, and soil compaction [3]. The study by Liu et al. [62] focuses on the soil degradation due to grain production in the north-east region, and documents that $31.4 \%$ and $7.9 \%$ respectively of the total area is moderately or severely water-eroded. The average annual decline in the rate of soil organic matter was $0.5 \%$. Proper adoption of crop rotation, tillage management, terraces and strip cultivation should be considered for erosion control and maintaining soil quality.

Pollution sources of agricultural soil are diverse, including mining, smelting, waste disposal, urban effluent, vehicle exhaust, sewage irrigation, pesticides, fertilizers application etc. In 2014, China published the results from the National Survey of Soil Pollution, which showed that $19.4 \%$ of agricultural land, $10 \%$ of forest land and $10.4 \%$ of grassland have been polluted. Pollution from inorganic pollutants $(\mathrm{Cd}, \mathrm{Ni}, \mathrm{Cu}, \mathrm{As}, \mathrm{Hg}, \mathrm{Pb}$ etc.) dominated $82.8 \%$ of contaminated sites, followed by organic pollutants such as HCH, DDT and PAHs [63]. Wei and Yang [64] review studies of heavy metal contamination in several cities in China and found that atmospheric deposition is responsible for $43-85 \%$ of the total As, $\mathrm{Cr}, \mathrm{Hg}, \mathrm{Ni}$ and $\mathrm{Pb}$ inputs to agricultural soils; livestock manure accounts for approximately $55 \%, 69 \%$ and $51 \%$ of the total $\mathrm{Cd}, \mathrm{Cu}$ and $\mathrm{Zn}$, respectively. Because of its significant toxicity, cadmium is a top priority for remediation in agricultural soils in China, with an average input rate of $0.004 \mathrm{mg} / \mathrm{kg} /$ year in the plough layer $(0-20 \mathrm{~cm})$. The sources of $\mathrm{Cd}, \mathrm{Hg}$ and As in agricultural soils in China are typically from pesticides and fertilizers. Khan et al. [57] find that heavy metal concentrations in plants grown in wastewater-irrigated soils are significantly higher than the standards of the World Health Organization. Soil pollution not only causes agricultural production loss and deteriorates product quality, but also raises concerns about health risks associated with consuming food crops grown on contaminated soil.

\subsection{Other Impacts}

The environmental impacts associated with agricultural production are not only limited to landscape, water and soil, but also include greenhouse gas emissions and biodiversity depletion.

Biodiversity: China is among the world's richest countries in terms of biodiversity because of wide geographic coverages of ecosystems. The ecosystem service provided by the rich biodiversity has greatly contributed to the prosperity of China's agricultural civilization. Meanwhile, the biodiversity still faces enormous threats due to the combined effects of habitat destruction, fragmentation, environmental contamination, over-exploitation of natural resources, and introduction of exotic species.

There are many biodiversity-friendly elements in the traditional Chinese agricultural systems that are conspicuously missing in modern agricultural production. The loss of biodiversity in the agricultural landscape is related to agricultural production intensification as shown in many studies conducted in Europe [65]. As agricultural production intensifies, expansion of agricultural and habitat fragmentation becomes common. The lack of related policies and clearly defined biodiversity conservation strategy constitute major challenges in the future. As a case study of landscape transformation in south-west China has shown, the decrease of agro-biodiversity is linked to the decline of swidden cultivation, a traditional form of agricultural production [60]. Liu et al. [65] argues that many more policy supports are required to support biodiversity-friendly agricultural practices, such as dyke-pond, rice-fishery systems, proper crop rotations, etc.

Greenhouse gas emissions: Agricultural activities are important sources of greenhouse gas (GHG) emissions globally. In China, they account for $17 \%$ of the total GHG emissions, and there are practices that can be adopted to reduce GHG emissions, such as a proper application of agro-chemicals, improving ruminant nutrients and intermittent irrigation of rice paddy fields [66]. Nitrogenous fertilizer overuse not only contributes to soil, water pollution and air pollution, but also is a source 
of greenhouse gas emissions: for every ton of $\mathrm{N}$ fertilizer manufactured and consumed, 13.5 tons of $\mathrm{CO}_{2}$-equivalent are emitted in China [25]. As the world's largest producer and consumer of $\mathrm{N}$ fertilizer, China's effort is essential for reducing N-related greenhouse gas.

\section{Policy Interventions, Unintended Effects and Conflicts}

The intrinsic connections between agriculture and environment are self-evident. On the one hand, healthy environmental conditions provide the fundamental, natural endowment required for agriculture. On the other hand, agricultural production has been recognized as a significant source of environmental harm [67]. The successful expansion of Chinese agriculture and its impressive improvement in productivity incur high costs in terms of the degradation of ecosystems and their services. The damaging consequences can be seen both through direct impacts on land-cover change and indirect impacts through air, water and soil etc. The environment has only been emphasized more in recent years. The Chinese government has put efforts into addressing this issue. This section is devoted to reviewing major policies to reduce the negative environmental impacts of agricultural production and conflicts between conservation and agricultural policies.

\subsection{Policy Interventions in Addressing Environmental Externalities from Agricultural Production}

As in other sectors, in the agricultural sector environmental protection often requires a sacrifice in productivity. The environmental performance in the agricultural sector has remained poor [3] and it was not until recent years, with growing understanding and awareness about land pollution and related health risks, that agricultural pollution control (such as reduction in chemical uses or abatement of non-point source pollution) became a priority in the country's policy agenda.

Direct command and control policies such as standards and rules regulating agricultural pollution have been gradually established to reduce water pollution from livestock and agrochemical applications and air pollution from biomass combustion by former Ministry of Environment and Protection (currently restructured to be Ministry of Ecological Environment). For example, biomass combustion in the harvest season causes severe air pollution in rural areas and is, therefore, strictly prohibited and monitored by remote-sensing technologies. Crop residuals are encouraged to be recycled in situ, or used for livestock feed and bio-energy generation with the support of government subsidies to farmers or to biomass processing companies. In 2015, the Ministry of Agriculture set goals for agricultural chemical use control, aiming to cap the growth of fertilizer and pesticide uses by 2020. The alternative approaches include improving the efficiency of chemical use, the application of formula fertilizer determined by soil testing, recycling agricultural waste (such as livestock manure, crop residuals), etc. It is reported that the cap goal was achieved in 2017, three years ahead of the scheduled timeline [68]. Conservation policies have also been adopted to reduce the ecological impact of agriculture by the former State Forestry Administration. For example, the Sloping Land Conversion Program (SLCP) was enacted after the great floods in 1998 to address the soil-erosion problem.

\subsection{Policies Conflicts and Integration}

In the agriculture-environment nexus, the policies in different sectors are not always consistent and sometimes even contradict to one another at different levels, and public policy may have unintended consequences, especially when policies change the behavioral incentives of certain stakeholders. It requires careful designs and more efforts to integrate policies in the system coherently.

In terms of policy goals, there are tradeoffs between conservation policy goals and agricultural policy goals of improving productivities. Take the SLCP, the largest conservation policy in China, for example. The program provides various forms of payments to farmers to encourage marginal cropland conversion to forest or grassland in order to reduce soil erosion. The program enjoyed an enormous total budget of 337 billion Chinese yuan by 2003, with some 7.2 million hectares of cropland already retired $[69,70]$. However, during the same period, in order to improve the agricultural productivity and farmers' wellbeing, a large number of direct subsidies were appropriated to encourage grain 
production. Such direct incentives, along with rising commodity prices, and other forces driven by government policies (such as livestock promotion programs), are bound to have an effect on SLCP participation and the efficacy of the policy [71]. Furthermore, there are internal conflicts in the agriculture-environment system, the core of which is competing land uses. The SLCP converts cultivated land for ecological use. On the other hand, with scarce arable land and a large population, the pressure of food security is pressing. The government has set a redline for cropland as a political goal to guarantee food security. With ongoing sprawl associated with urbanization, re-zoning arable lands for residents' settlement adds to the tensions of competing land uses for agricultural production and conservation. The poorly coordinated policy system itself generates conflicts over competing land uses for conservation versus those required for agricultural production.

Unintended policy effects are not rare in the policy arena and require careful policy design. Given the intrinsic contradiction between environmental protection and agriculture production, conflicts may surface in a range of different policies. For instance, the target price policy for corn in the north-east region was originally set goals to reducing price risks farmers facing, and unintendedly expanded the acreage of corn production while reducing the acreages of wheat and soybeans [72]. The negative environmental impacts are expected, as corn production has a greater negative impact on soil erosion and generates more crop residuals than wheat and soybeans. The conservation program, retirement or conversion of cultivated land, may also trigger unintended policy effects: farmers have less land to work on after land retirement or conversion, and they may further convert uncultivated land, mostly marginal lands which are ecologically sensitive. Such slippage effects, which have been recorded in conservation programs in other countries, such as, the Conservation Reserve Program in the U.S. [73] and the forest protection program in Mexico [74], need to be carefully monitored in SLCP, etc.

Another aspect that may complicate the conflicts is the way that the institution is operated and structured. In China, policy priorities are often affected by political signals at the time. For instance, if a policy priority issued by the central government is food security, then related conservation policy is likely to be compromised and vice versa. Moreover, the policies associated with the agriculture-environment nexus are often designed and executed by multiple sectors. For instance, the SLCP is administrated by Forestry authorities; the agricultural production policies are in the charge of the Agricultural authorities; the designation of cropland redline is under the jurisdiction of Land Resources authorities; the pollution standards, rules and regulatory enforcement associated with soil, water bodies, livestock production waste etc. are set by the Environmental authorities. The transaction cost of coordinating with different sectors can be cumbersome. The Chinese government is making efforts to integrate land-use planning into one policy framework, called the Major Function Oriented Zoning (MFOZ). To further improve the agriculture-environment nexus, it is necessary to identify and resolve conflicts and acquire deeper understandings of potential policy impacts and interactions under changing socio-economic conditions.

\section{Towards the Future: Food Security and Sustainability}

Looking towards the future, food security and sustainability will continue to be two primary goals of the agricultural sector in China. How China's agriculture could meet the country's food demand with higher quality and more varieties in a sustainable approach is a central challenge faced by the country.

In the past, food security meant simply that the agricultural sector could provide enough food for the country. It has been proven that with the right technology and institutional innovations, China can achieve this-and indeed, the agricultural sector has done remarkable work to achieve this goal. In the future, innovations will continue to be a key driver for the growth of agriculture, including expanded utilization of GM crops, machinery uses, and land/institutional reforms. For instance, as many of the most efficient farm equipment is better suited for large farms, the continued land reform, Separation of Three Rights relating to Agricultural Land (San-quan-fen-zhi, in Chinese pinyin) 
encouraging land transfers can facilitate a transition to larger farms and more efficient farming practices. Another institutional innovation, Major Function Oriented Zoning (MFOZ) is potentially helpful to resolve the competing land uses between agricultural policies and conservation policies. It delineates land into four types of zones by functions: development-optimized zones and development-prioritized zones for massive urbanization and industrialization; development-restricted zones for ecological safety and food production; development-prohibited zones for protection of natural and cultural heritage [75]. As part of a clear and well considered zoning process, policy priorities are set for each zone. This can potentially reduce policy conflicts and guarantee food production while protecting the environmentally vulnerable regions at the same time.

As China's socio-economic conditions change, the concept of food security has come to have several meanings, not only referring to the quantity of food but also quality issues. For instance, food safety is a great challenge now and will continue to be so in the future, especially given the current degraded status of much of the country's soil and water resources. Pernicious substances could potentially be found in the food supply which might be originally from water and soil, exposing consumers to a range of health risks. Since the National Survey of Soil Pollution was released in 2014, the central government of China has started to put intensive efforts to restore China's contaminated soil and water, by establishing a special fiscal fund in 2015 and issuing management rules in 2017. But this will be a long process, and public participation and social supervision need to play key roles in preventing contaminants entering the food chain.

Furthermore, as income increases, higher food quality and more diversified dietary expectations will place greater pressures and requirements on the country's agricultural sector. Agricultural species and genetics conservation, and more eco-friendly cropping systems, such as an integrated rice-fishery system, should be encouraged. These not only can provide high-quality food on the table, but are also beneficial to the environment and agro-biodiversity. Improved technology, such as cost-effective bio-energy generation, may help recycle residuals to solve the air and water pollution problem caused by crop straw or livestock manure, and will also provide new opportunities for the utilization of sustainable energies in rural area.

Given the relatively recent history of famine, food shortages and starvation, China has done an exceptional job in meeting the food demands of the country. However, progress has come at a price. Keeping the agriculture-environment nexus on a more sustainable track constitutes great challenges today and in the future. Looking towards this future, both challenges and opportunities exist. Technological innovation still remains the primary driver of agriculture growth. In March 2018, China also undertook substantial institutional reform on the structure of central government, by establishing the new Ministry of Natural Resources to end the bureaucratic fragmentation of land planning, and integrating regulatory responsibilities of pollution control (including agricultural pollution) into the new Ministry of Ecological Environment, which is expected to facilitate establishing a coherent policy system that attains agricultural-environmental objectives.

Author Contributions: J.W. was invited to design the study and provided project support for the study. J.Y. did the literature survey and data analysis; J.Y. and J.W. drafted and revised the manuscript. Both authors have read and approved the final manuscript.

Acknowledgments: The authors gratefully acknowledge the financial support from National Natural Science Foundation of China (Project No. 41571519) and National Social Science Foundation of China (Project No. 18VSJ100). The authors wish to thank Alon Tal and three anonymous reviewers for their constructive suggestions on the paper.

Conflicts of Interest: The authors declare no conflict of interest.

\section{References}

1. Liu, X.; Zhang, X.; Herbert, S.J. Feeding China's growing needs for grain. Nature 2010, 465, 420. [CrossRef] [PubMed] 
2. Bawa, K.S.; Koh, L.P.; Lee, T.M.; Liu, J.; Ramakrishnan, P.S.; Yu, D.W.; Zhang, Y.; Raven, P.H. China, India, and the Environment. Science 2010, 327, 1457-1459. [CrossRef] [PubMed]

3. Liu, J. China's Road to Sustainability. Science 2010, 328, 50. [CrossRef] [PubMed]

4. Norse, D.; Ju, X. Environmental costs of China's food security. Agric. Ecosyst. Environ. 2015, 209, 5-14. [CrossRef]

5. Jin, S.; Ma, H.; Huang, J.; Hu, R.; Rozelle, S. Productivity, efficiency and technical change: Measuring the performance of China's transforming agriculture. J. Prod. Anal. 2010, 33, 191-207. [CrossRef]

6. Lin, J.Y. Rural reforms and agricultural growth in China. Am. Econ. Rev. 1992, 82, 34-51.

7. McMillan, J.; Whalley, J.; Zhu, L. The impact of China's economic reforms on agricultural productivity growth. J. Political Econ. 1989, 97, 781-807. [CrossRef]

8. Huang, J.; Rozelle, S. Technological change: Rediscovering the engine of productivity growth in China's rural economy. J. Dev. Econ. 1996, 49, 337-369. [CrossRef]

9. Sayer, J.; Sunderland, T.; Ghazoul, J.; Pfund, J.-L.; Sheil, D.; Meijaard, E.; Venter, M.; Boedhihartono, A.K.; Day, M.; Garcia, C. Ten principles for a landscape approach to reconciling agriculture, conservation, and other competing land uses. Proc. Natl. Acad. Sci. USA 2013, 110, 8349-8356. [CrossRef] [PubMed]

10. Xie, J.; Hu, L.; Tang, J.; Wu, X.; Li, N.; Yuan, Y.; Yang, H.; Zhang, J.; Luo, S.; Chen, X. Ecological mechanisms underlying the sustainability of the agricultural heritage rice-fish coculture system. Proc. Natl. Acad. Sci. USA 2011, 108, E1381-E1387. [CrossRef] [PubMed]

11. Carberry, P.S.; Liang, W.; Twomlow, S.; Holzworth, D.P.; Dimes, J.P.; McClelland, T.; Huth, N.I.; Chen, F.; Hochman, Z.; Keating, B.A. Scope for improved eco-efficiency varies among diverse cropping systems. Proc. Natl. Acad. Sci. USA 2013, 110, 8381-8386. [CrossRef] [PubMed]

12. Bromley, D.W. Food Security: Beyond Technology. Science 2010, 328, 169. [CrossRef] [PubMed]

13. Huang, P.C.C. Is the family farm the approach for agricultural development in China? Open Times 2014, 2, 176-194.

14. Brown, L.R. Who Will Feed China? Wake-Up Call for a Small Planet; W.W. Norton and Company: New York, NY, USA; ISBN 0-393-31049-X.

15. Rozelle, S.; Rosegrant, M.W. China's past, present, and future food economy: Can China continue to meet the challenges? Food Policy 1997, 22, 191-200. [CrossRef]

16. Cao, K.H.; Birchenall, J.A. Agricultural productivity, structural change, and economic growth in post-reform China. J. Dev. Econ. 2013, 104, 165-180. [CrossRef]

17. Carr, D.L.; Lopez, A.C.; Bilsborrow, R.E. The population, agriculture, and environment nexus in Latin America: Country-level evidence from the latter half of the twentieth century. Popul. Environ. 2009, 30, 222-246. [CrossRef]

18. Wei, Y.D.; Ye, X. Urbanization, urban land expansion and environmental change in China. Stoch. Environ. Res. Risk Assess. 2014, 28, 757-765. [CrossRef]

19. Li, Z.; Zhang, H. Productivity Growth in China's Agriculture During 1985-2010. J. Integr. Agric. 2013, 12, 1896-1904. [CrossRef]

20. Lin, J.Y. Collectivization and China's Agricultural Crisis in 1959-1961. J. Political Econ. 1990, 98, $1228-1252$. [CrossRef]

21. Huang, J.; Wang, X. Evolution and consequences of China's rural land institutional reform. J. Law Rural Dev. 2017, 1, 59-64.

22. Liu, Y.; Wang, X. Technological progress and Chinese agricultural growth in the 1990s. China Econ. Rev. 2005, 16, 419-440. [CrossRef]

23. Jin, L.; Young, W. Water use in agriculture in China: Importance, challenges, and implications for policy. Water Policy 2001, 3, 215-228. [CrossRef]

24. Liu, J.; Wiberg, D.; Zehnder, A.J.B.; Yang, H. Modeling the role of irrigation in winter wheat yield, crop water productivity, and production in China. Irrig. Sci. 2007, 26, 21-33. [CrossRef]

25. Zhang, W.; Dou, Z.; He, P.; Ju, X.-T.; Powlson, D.; Chadwick, D.; Norse, D.; Lu, Y.-L.; Zhang, Y.; Wu, L. New technologies reduce greenhouse gas emissions from nitrogenous fertilizer in China. Proc. Natl. Acad. Sci. USA 2013, 110, 8375-8380. [CrossRef] [PubMed]

26. Huang, J.; Gulati, A.; Gregory, I. Fertilizer Subsidies-Which Way Forward? Available online: An IFDC/FAI Report 2017. https: / /ifdcorg.files.wordpress.com/2017/02/fertilizer-subsidieswhich-way-forward-2-212017.pdf (accessed on 23 May 2018).

27. Parisi, C.; Tillie, P.; Rodríguez-Cerezo, E. The global pipeline of GM crops out to 2020. Nat. Biotechnol. 2016, 34, 31-36. [CrossRef] [PubMed] 
28. Cai, J.; Hu, R.; Huang, J.; Wang, X. Innovations in genetically modified agricultural technologies in China's public sector: Successes and challenges. China Agric. Econ. Rev. 2017, 9, 317-330. [CrossRef]

29. Qiao, F. Fifteen Years of Bt Cotton in China: The Economic Impact and its Dynamics. World Dev. 2015, 70, 177-185. [CrossRef]

30. Huang, J.; Hu, R.; Qiao, F.; Yin, Y.; Liu, H.; Huang, Z. Impact of insect-resistant GM rice on pesticide use and farmers' health in China. Sci. China Life Sci. 2015, 58, 466-471. [CrossRef] [PubMed]

31. Lin, S.; Ye, W.; Zhang, L. Whether labor migration can improve mechanization in agricultural secto? An analysis of translog cost function. J. Agrotech. Econ. 2017, 7, 4-17.

32. Liu, Y.; Wang, C.; Tang, Z.; Nan, Z. Farmland Rental and Productivity of Wheat and Maize: An Empirical Study in Gansu, China. Sustainability 2017, 9, 1678. [CrossRef]

33. Wang, X.; Yamauchi, F.; Otsuka, K.; Huang, J. Wage Growth, Landholding, and Mechanization in Chinese Agriculture. World Dev. 2016, 86, 30-45. [CrossRef] [PubMed]

34. National Bureau of Statistics of China National Data, 1982-2016. Available online: http:/ / data.stats.gov.cn/ english/easyquery.htm?cn=C012017 (accessed on 23 May 2018).

35. United Nations, Department of Economic and Social Affairs, Population Division (2013). World Population Prospects: The 2012 Revision, Highlights and Advance Tables. Working Paper No. ESA/P/WP.228. 2013. Available online: https://esa.un.org/unpd/wpp/publications/Files/WPP2012_HIGHLIGHTS.pdf (accessed on 23 May 2018).

36. Yang, H.; Li, X. Cultivated land and food supply in China. Land Use Policy 2000, 17, 73-88. [CrossRef]

37. Bao, H.; Wu, C. Discuss on the construction of security system of landless peasant. Manag. World 2002, 10, $37-42$.

38. Liu, Y. Give landless peasant a solid and reliable future. People's Dly. 09/29/2010, A07. Available online: http:/ / unn.people.com.cn/GB/14748/12856447.html (accessed on 23 May 2018).

39. Zhang, K.H.; Song, S. Rural-urban migration and urbanization in China: Evidence from time-series and cross-section analyses. China Econ. Rev. 2003, 14, 386-400. [CrossRef]

40. De Brauw, A.; Giles, J. Migrant Labor Markets and the Welfare of Rural Households in the Developing World: Evidence from China. World Bank Econ. Rev. 2018, 32, 1-18. [CrossRef]

41. Jiang, L.; Deng, X.; Seto, K.C. The impact of urban expansion on agricultural land use intensity in China. Land Use Policy 2013, 35, 33-39. [CrossRef]

42. Popkin, B.M.; Horton, S.; Kim, S.; Mahal, A.; Jin, S. Trends in Diet, Nutritional Status, and Diet-related Noncommunicable Diseases in China and India: The Economic Costs of the Nutrition Transition. Nutr. Rev. 2009, 59, 379-390. [CrossRef]

43. Liu, J.; Diamond, J. China's environment in a globalizing world. Nature 2005, 435, 1179. [CrossRef] [PubMed]

44. Long, H.; Liu, Y.; Wu, X.; Dong, G. Spatio-temporal dynamic patterns of farmland and rural settlements in $\mathrm{Su}-\mathrm{Xi}-\mathrm{Chang}$ region: Implications for building a new countryside in coastal China. Land Use Policy 2009, 26, 322-333. [CrossRef]

45. Wu, Y.; Su, Y.; Zhang, L. Economic structure transformation and land use change of the Changjiang River Basin. Chin. Geogr. Sci. 2006, 16, 289-293. [CrossRef]

46. Quan, B.; Zhu, H.-J.; Chen, S.-L.; Römkens, M.J.M.; Li, B.-C. Land Suitability Assessment and Land Use Change in Fujian Province, China. Pedosphere 2007, 17, 493-504. [CrossRef]

47. Wei, Y.H.D. Restructuring for growth in urban China: Transitional institutions, urban development, and spatial transformation. Habitat Int. 2012, 36, 396-405. [CrossRef]

48. Tan, M.; Li, X.; Xie, H.; Lu, C. Urban land expansion and arable land loss in China-A case study of Beijing-Tianjin-Hebei region. Land Use Policy 2005, 22, 187-196. [CrossRef]

49. Xu, H.; Wang, X.; Xiao, G. A remote sensing and GIS integrated study on urbanization with its impact on arable lands: Fuqing City, Fujian Province, China. Land Degrad. Dev. 2000, 11, 301-314. [CrossRef]

50. Gao, J.; Liu, Y.; Chen, Y. Land cover changes during agrarian restructuring in Northeast China. Appl. Geogr. 2006, 26, 312-322. [CrossRef]

51. Song, K.; Wang, Z.; Li, L.; Tedesco, L.; Li, F.; Jin, C.; Du, J. Wetlands shrinkage, fragmentation and their links to agriculture in the Muleng-Xingkai Plain, China. J. Environ. Manag. 2012, 111, 120-132. [CrossRef] [PubMed]

52. Su, S.; Ma, X.; Xiao, R. Agricultural landscape pattern changes in response to urbanization at ecoregional scale. Ecol. Indic. 2014, 40, 10-18. [CrossRef] 
53. Qi, Z.-F.; Ye, X.-Y.; Zhang, H.; Yu, Z.-L. Land fragmentation and variation of ecosystem services in the context of rapid urbanization: The case of Taizhou city, China. Stoch. Environ. Res. Risk Assess. 2014, 28, 843-855. [CrossRef]

54. Fang, Q.X.; Ma, L.; Green, T.R.; Yu, Q.; Wang, T.D.; Ahuja, L.R. Water resources and water use efficiency in the North China Plain: Current status and agronomic management options. Agric. Water Manag. 2010, 97, 1102-1116. [CrossRef]

55. Liu, J.; Yang, W. Water Sustainability for China and Beyond. Science 2012, 337, 649-650. [CrossRef] [PubMed]

56. Ju, X.T.; Kou, C.L.; Zhang, F.S.; Christie, P. Nitrogen balance and groundwater nitrate contamination: Comparison among three intensive cropping systems on the North China Plain. Environ. Pollut. 2006, 143, 117-125. [CrossRef] [PubMed]

57. Khan, S.; Cao, Q.; Zheng, Y.M.; Huang, Y.Z.; Zhu, Y.G. Health risks of heavy metals in contaminated soils and food crops irrigated with wastewater in Beijing, China. Environ. Pollut. 2008, 152, 686-692. [CrossRef] [PubMed]

58. Lu, Y.; Song, S.; Wang, R.; Liu, Z.; Meng, J.; Sweetman, A.J.; Jenkins, A.; Ferrier, R.C.; Li, H.; Luo, W.; et al. Impacts of soil and water pollution on food safety and health risks in China. Environ. Int. 2015, 77, 5-15. [CrossRef] [PubMed]

59. Qiu, G.; Jin, Y.; Geng, S. Impact of climate and land-use changes on water security for agriculture in Northern China. J. Integr. Agric. 2012, 11, 144-150. [CrossRef]

60. Guo, R.; Lin, Z.; Mo, X.; Yang, C. Responses of crop yield and water use efficiency to climate change in the North China Plain. Agric. Water Manag. 2010, 97, 1185-1194. [CrossRef]

61. Piao, S.; Ciais, P.; Huang, Y.; Shen, Z.; Peng, S.; Li, J.; Zhou, L.; Liu, H.; Ma, Y.; Ding, Y.; et al. The impacts of climate change on water resources and agriculture in China. Nature 2010, 467, 43-51. [CrossRef] [PubMed]

62. Liu, X.B.; Zhang, X.Y.; Wang, Y.X.; Sui, Y.Y.; Zhang, S.L.; Herbert, S.J.; Ding, G. Soil degradation: A problem threatening the sustainable development of agriculture in Northeast China. Plant Soil Environ. 2010, 56, 87-97. [CrossRef]

63. National Survey of Soil Pollution. 2014. Available online: http://www.zhb.gov.cn/gkml/hbb/qt/201404/ t20140417_270670.htm (accessed on 23 May 2018).

64. Wei, B.; Yang, L. A review of heavy metal contaminations in urban soils, urban road dusts and agricultural soils from China. Microchem. J. 2010, 94, 99-107. [CrossRef]

65. Liu, Y.; Duan, M.; Yu, Z. Agricultural landscapes and biodiversity in China. Agric. Ecosyst. Environ. 2013, 166, 46-54. [CrossRef]

66. Dong, H.; Li, Y.; Tao, X.; Peng, X.; Li, N.; Zhu, Z. China greenhouse gas emissions from agricultural activities and its mitigation strategy. Trans. Chin. Soc. Agric. Eng. 2008, 26, 269-273.

67. Millennium Ecosystem Assessment (Program) (Ed.) Ecosystems and Human Well-Being: Synthesis; Island Press: Washington, DC, USA, 2005; ISBN 978-1-59-726040-4.

68. The cap goal of agro-chemical application is achieved. Peoples Daily, 22 Decembr 2017. Available online: http:/ / paper.people.com.cn/rmrb/html/2017-12/22/nw.D110000renmrb_20171222_3-10.htm (accessed on 23 May 2018).

69. Uchida, E.; Xu, J.; Xu, Z.; Rozelle, S. Are the poor benefiting from China's land conservation program? Environ. Dev. Econ. 2007, 12, 593-620. [CrossRef]

70. Tao, R.; Xu, Z.; Xu, J. Grain for green project, grain policy and sustainable development. Soc. Sci. China 2004, $150,25-38$.

71. Komarek, A.M.; Shi, X.; Heerink, N. Household-level effects of China's Sloping Land Conversion Program under price and policy shifts. Land Use Policy 2014, 40, 36-44. [CrossRef]

72. Dong, F.; Liu, A.; Feng, Z.; Xue, L.; Yang, X. Changes of Planting Structure and Quantitative Evaluation of Influencing Factors in Traditional Soybean Producing Areas: Taking Nenjiang County in Heilongjiang Province as an Example. J. Nat. Resour. 2017, 32, 40-49. 
73. Wu, J.J. Slippage Effects of the Conservation Reserve Program. Am. J. Agric. Econ. 2000, 82, 979-992. [CrossRef]

74. Alix-Garcia, J.M.; Shapiro, E.N.; Sims, K.R.E. Forest Conservation and Slippage: Evidence from Mexico's National Payments for Ecosystem Services Program. Land Econ. 2012, 88, 613-638. [CrossRef]

75. Fan, J.; Wei, S.; Kan, Z.; Dong, C. Major Function Oriented Zone: New Method of Spatial Regulation for Reshaping Regional Development Pattern in China. Chin. Geogr. Sci. 2012, 22, 196-209. [CrossRef] 